\title{
IAMJ
}

INTERNATIONAL

AYURVEDIC

MEDICAL JOURNAL

\section{JUDICIAL UTILIZATION OF KUPIPAKWA AND POTTALI RASAYANAS BOON FOR AYURVEDIC PRACTICE}

\author{
$\underline{\text { Kannan Mani }}^{1}$, $\underline{\text { Priyanka K. Dighde }}^{2}$, $\underline{\text { Sheetal Agrawal }}^{3}, \underline{\text { Ashish Agrawal }}^{4}$
}

${ }^{1}$ Professor and HOD (Rachana Sharir), Jupiter Ayurved Medical college and Tarini Ayurved Hospital, Shankarpur, Nagpur, Maharashtra, India

${ }^{2}$ M.D. Rasashastra and Bhaishajyakalpana;

${ }^{3}$ M.D. Rasashastra and Bhaishajyakalpana;

${ }^{4}$ Professor \& HOD (Kriya Sharir),

Vimladevi Ayurvedic Medical College, Chandrapur, Maharashtra, India

Corresponding Author: drpriyankadighde@gmail.com

\section{https://doi.org/10.46607/iamj08p5052021}

(Published online: July 2021)

Open Access

(C) International Ayurvedic Medical Journal, India 2021

Article Received: 20/06/2021 - Peer Reviewed: 02/07/2021 - Accepted for Publication: 12/07/2021

\section{Check for updates}

\begin{abstract}
Parada Murchana (Mercurial Preparations) forms the backbone of Rasashastra which signifies the formulations of mercury after Shodhan (purification) termed as Rasachikitsa which includes Kharaliya, Parpati Kupipakwa \& Pottali Rasayanas. Amongst them, Kupipakwa Rasayana (KPR) \& Pottali Rasayana (PTR) are unique pharmaceutical preparations designed to achieve potential therapeutic efficacy by stabilizing the stronger bonds between ingredients. Judicial utilization of these mercurial preparations provides quicker action and synergistic effects with suitable Anupana (adjuvants), Kala (time) at low doses without producing toxic effects. KPR and PTR give miraculous results in Complicated, Chronic as well as Acute conditions. In the present era, people hesitate to use these medicines due to a lack of knowledge $\&$ awareness. This review aims to bring into the limelight the importance of KPR \& PTR in the modern era where modern medicines have failed or attained resistance against diseases and also to overcome difficulties that may arise because of the extinction of many herbal drugs.
\end{abstract}

Keywords: Kupipakwa, Pottali, Rasayana, Rasachikitsa, Murchana, Mercurial preparations 


\section{INTRODUCTION}

Ayurveda translates as 'life science', the oldest of the traditional systems of medicine accepted worldwide. Rasashastra, a branch of Ayurveda, the miracle mercurial system deals with pharmaceutical aspects of minerals, metals, precious stones, certain poisons into therapeutically potent special formulations to combat diseases difficult to treat. Parad (Mercury) is one of the metals which attracted the wide attention of ayurvedic chemists and physicians. Indeed, the documentation of chemical and physical processes involving mercury is truly enormous in ancient texts of which classics by Vagabhata and Nagarjuna are noteworthy. Parad Murchana ${ }^{[1]}$ signifies the formulations of mercury after Shodhan (purification) termed as Rasachikitsa which is further classified into Kharaliya, Parpati, Kupipakva, and Pottali Rasayanas ${ }^{[2]}$. During the preparation of Rasaushadhis (Herbometallic formulations) temperature plays a very important role to get the desired and beneficial effect in the final product. Amongst them KPR and PTR being rare, unique, potent, time tested, novel molecules, and clinically proved to be good, it is not freely available in the market owing to its complexity in preparation procedure and as a result of this, its usage has been relegated to oblivion. Keeping the said facts in view, an attempt has been made to unravel the lost glory of this novel medicine. The safety and efficacy of metallic preparations have always been a concern. Research scholars have undertaken Constant efforts in various institutes and were found to be safe for clinical use at therapeutic doses. The dose is very important in all fields of medicine. The dose is that which differentiates Medicine and Poison.

\section{Aim \& Objectives:}

This present article aims to summarize the detailed knowledge regarding various $K P R$ and $P T R$, their constituents, doses, and their application in Ayurvedic Practice.

\section{Methodology:}

Rasachikitsa comprises of

1. Kharaliya Rasayana: Drugs prepared by grinding in a mortar (Kharal) and pestle are called Kharaliya drugs. Here Murchana of Parad takes place due to heat generated with the continuous rotation of pestle in a mortar e.g. Kajjali, ${ }^{[3]}$

2. Parpati Rasayana: Kajjali prepared in Kharaliya form is being melted and further distributed over Clarified butter oil-smeared leaves kept over Cow dung slab, and then, it is pressed from above by other leaves and Cow dung slab over it and cooled, resulting in strong bond as compared to Kharaliya $K_{\text {Kalpa }}{ }^{[4]}$ e.g. Rasaparpati, Swarnaparpati, etc.

3. Kupipakwa Rasayana ${ }^{[5]}$ : The terminology 'Kupipakwa' itself denotes the pharmaceutical processing that is carried out in a specially designed glass bottle by gradual heating immersion in a sand bath (Valuka Yantra). Chemical processes are involved in these preparations which also bear testimony to the great chemical knowledge prevailing in ancient India.

4. Pottali Rasayana ${ }^{[6]}$ : Rasayana in which the ingredients are made into a compact and comprehensive size and shape or processing technique which gives compactness to scattered material. The important methods are.

1. By boiling amidst liquid Sulphur.

2. Kaparda Poorana / Sukti Poorana method - filling the drugs inside cowries/oysters.

3. Processed by incineration - Puta Paka method

4. Bhavana - Trituration method. 
Table 1: Some of the Kupipakwa Rasayanas (KPR) is given below

\begin{tabular}{|c|c|c|c|c|}
\hline Sr.no & Kupipakwa Rasayana & Constituents & Dose \& Anupana & Diseases \\
\hline 1 & $\begin{array}{l}\text { Rasa sindoor } \\
\text { Sama-Gandhak -Jarit }{ }^{[7]}\end{array}$ & $\begin{array}{l}\text { Sh. Parad- } 1 \text { part } \\
\text { Sh. Gandhaka -1 part }\end{array}$ & $\begin{array}{l}\text { 1-2 Ratti. }(125-250 \\
\text { mg/day) } \\
\text { Honey, Trikatu, Bharangi } \\
\text { Swaras (Clerodendrum } \\
\text { serratum juice) }\end{array}$ & $\begin{array}{l}\text { Gulma, } \\
\text { Rajayakshma, Visphota. }\end{array}$ \\
\hline 2 & $\begin{array}{l}\text { Shadgunabalijarita } \\
\text { Rasasindoor }{ }^{[8]} \quad \text { (Rasa } \\
\text { tarangini) }\end{array}$ & $\begin{array}{l}\text { Sh. Parad- } 1 \text { Pala }=50 \\
\text { gms } \\
\text { Sh. Gandhaka-6 } \\
\text { Pala=300 gms } \\
\text { Trituration with } \\
\text { Indian aloe juice } \\
\text { (Bhavana) }\end{array}$ & $\begin{array}{l}\text { According to different } \\
\text { Anupanas [23] }\end{array}$ & $\begin{array}{l}\text { Prameha, } \\
\text { Bhagandar (Fistula in Ano), } \\
\text { Gulma, Kushtha (skin } \\
\text { disorders), } \\
\text { Pandu, } \\
\text { Sthulta (Obesity) etc. }\end{array}$ \\
\hline 3 & Sameer pannga rasa ${ }^{[9]}$ & $\begin{array}{l}\text { Sh. Parad- } 1 \text { part } \\
\text { Sh. Gandhaka-1 part } \\
\text { Sh. Somala }-1 \text { part } \\
\text { Sh. Hartaaala- } 1 \text { part } \\
\text { Sh. Manashila- } 1 \text { part }\end{array}$ & $\begin{array}{l}1 / 2 \quad \text { Gunja-1 Gunja (60- } \\
120 \mathrm{mg}) \\
\text { nagavallidal } \\
\text { (Betel leaf) }\end{array}$ & $\begin{array}{l}\text { Vaat Pradhan Sannipata, } \\
\text { Khaphaj Unmaad } \\
\text { Khaphaj Sandhivaat } \\
\text { Kaphaj Vikar }\end{array}$ \\
\hline 4 & $\begin{array}{l}\text { Makardhwaja }^{[10]} \\
(\text { Purna Chandrodaya) }\end{array}$ & $\begin{array}{l}\text { Sh. Suvarna- } 1 \text { part } \\
\text { Sh. Parad- } 8 \text { parts } \\
\text { Sh. Gandhak }-16 \\
\text { parts }\end{array}$ & $\begin{array}{l}15 \mathrm{mg}-30 \mathrm{mg} \\
\text { butteroil, Honey } \\
\text { Nagvallidal (Betel leaf) }\end{array}$ & $\begin{array}{l}\text { Dhatu Kshaya } \\
\text { Tarunya Sthapak } \\
\text { Vali Palitnashak } \\
\text { Vrushya, Kshaya }\end{array}$ \\
\hline 5 & $\begin{array}{l}\text { Rasa Karpoor } \\
{[11]}\end{array}$ & $\begin{array}{l}\text { Sh. Parad -1 Pala } \\
\text { (50gms) } \\
\text { Gandhakaamla } \\
\text { (Sulphuric acid) }-1 \\
1 / 2 \text { Pala }(75 \mathrm{gms}) \\
\text { Rock salt- in equal } \\
\text { quantity }\end{array}$ & $\begin{array}{l}1 / 64-1 / 32 \text { Ratti } \\
(2-4 \mathrm{mg})\end{array}$ & $\begin{array}{l}\text { Krimivisha (Toxins), Rakta } \\
\text { Dosha, Grahni, Sphota, } \\
\text { Mandaladi Kushtha (Skin } \\
\text { disorders) } \\
\text { Krumi(worms) }\end{array}$ \\
\hline 6 & Rasa Pushpa ${ }^{[12]}$ & $\begin{array}{l}\text { Sh. Parada-50 gms } \\
\text { Rock salt-50 gms } \\
\text { Sh. Kasis }-50 \mathrm{gms}\end{array}$ & $\begin{array}{l}\text { 1/2-21/2 Ratti }(60-300 \mathrm{mg}) \\
\text { - Virechan-2 } 1 / 2 \text { Ratti - } \\
\quad(300 \mathrm{mg}) \\
\text { - Hikka- } 1 \text { Tandul } \\
\text { - Firang-1/4 Ratti (30mg) } \\
\text { - Baalavirechan-1/2 Ratti } \\
\quad(60 \mathrm{mg})\end{array}$ & $\begin{array}{l}\text { Pittahar } \\
\text { Pitta Virechak } \\
\text { Mutral, Krimi (Worms) } \\
\text { Vrana Dosha (Infected } \\
\text { wounds) } \\
\text { Visuchika, Jalodar (Ascitis), } \\
\text { Hikka, Firang (syphilis) }\end{array}$ \\
\hline 7 & Vyadhiharan Rasa ${ }^{[13]}$ & $\begin{array}{l}\text { Sh. Parad-1 part } \\
\text { Sh. Gandhak- } 1 \text { part } \\
\text { RasaKarpoor-2 parts }\end{array}$ & $\begin{array}{l}\begin{array}{l}1-4 \quad \text { Gunja } \quad(125-500 \\
\mathrm{mg} / \text { day) }\end{array} \\
\text { Nagavallidal (betel leaf) }\end{array}$ & $\begin{array}{l}\text { Upadamsh (Gonorrhea), } \\
\text { Vajikarana, (Aphrodiasic), } \\
\text { Apatya Prapti (Fertility), } \\
\text { Hrudaya Shoola, } \\
\text { Vali-Palit }\end{array}$ \\
\hline 8 & Mallasindoor ${ }^{[14]}$ & $\begin{array}{l}\text { Sh. Parad- } 9 \text { Karsha } \\
(90 \mathrm{gms}) \\
\text { Sh. Gandhak- } 5 \quad 1 / 2 \\
\text { Karsha }(55 \mathrm{gms})\end{array}$ & $32.5-64 \mathrm{mg} / \mathrm{day}$ & $\begin{array}{l}\text { Upadamsh, Kasa, Visuchika, } \\
\text { Vishamjvar and (Pneumonia, } \\
\text { Influenza) }\end{array}$ \\
\hline
\end{tabular}




\begin{tabular}{|c|c|c|c|c|}
\hline & & $\begin{array}{l}\text { Somal- } 4 \quad \text { Karsha } \\
\text { (40gms) } \\
\text { Rasakarpoor- } \quad 9 \\
\text { Karsha (90gms) }\end{array}$ & $\begin{array}{l}\text { Pippali (piper longum) and } \\
\text { Honey or Ginger juice and } \\
\text { Honey }\end{array}$ & \\
\hline 9 & Taalsindoor ${ }^{[15]}$ & $\begin{array}{l}\text { Sh. Parad, - } 6 \text { parts } \\
\text { Sh. Gandhak- } 1 \text { part } \\
\text { Sh. Hartal- } 1 \text { part } \\
\text { Sh. Somal -1 part }\end{array}$ & $\begin{array}{l}\text { 1-2 Ratti (125-250 mg/day) } \\
\text { Ginger juice, Honey or } \\
\text { Butter oil }\end{array}$ & $\begin{array}{l}\text { Kushta, Upadamsh, Kasa, } \\
\text { Kshaya }\end{array}$ \\
\hline 10 & Manikya Rasa ${ }^{[16]}$ & $\begin{array}{l}\text { Sh. Parad- } 8 \text { Pala } \\
\text { (40gms) } \\
\text { Sh. Naag- } 8 \text { Pala } \\
\text { Sh. Manashil- } 8 \text { Pala }\end{array}$ & $\begin{array}{l}\text { 1-2 Ratti (125-250 mg/day) } \\
\text { Honey }\end{array}$ & $\begin{array}{l}\text { Shukrastambha } \\
\text { Jara Vyadhi Vinash } \\
\text { Mahavyadhi Nashan } \\
\text { Rajayakshma }\end{array}$ \\
\hline 11 & $\begin{array}{l}\text { Panchasuta Rasa } \\
\text { Agasti Paath }\end{array}$ & $\begin{array}{l}\text { Sh. Parad -1 part } \\
\text { Sh. Hingul- 1 part } \\
\text { Sh. Somal- 1 part } \\
\text { Sh. Gandhak- } 1 \text { part } \\
\text { Rasasindoor - 1 part } \\
\text { Rasakarpoor- 1 part }\end{array}$ & $\begin{array}{l}1 / 2-1 \text { Ratti }(62-125 \\
\text { mg/day) } \\
\text { Ginger juice, Holy basil } \\
\text { juice, Honey }\end{array}$ & Urastoya (Pleuritis), Kasa \\
\hline 12 & $\begin{array}{l}\text { Swarnavang: } \\
\text { Suwarnarajvangeshwar: }\end{array}$ & $\begin{array}{l}\text { Sh. Vanga- } 1 \text { part } \\
\text { Sh. Parad- } 1 \text { part } \\
\text { Sh. Gandhak-1 part } \\
\text { Sh. Navasadar-1 part } \\
\text {-1/10 part }\end{array}$ & $\begin{array}{l}\text { 1-2 Ratti (125-250 mg/day) } \\
\text { Honey. }\end{array}$ & $\begin{array}{l}\text { Prameha, Balya, Rasayan } \\
\text { (Immunomodulator), } \\
\text { Medha Virya -Agni Vardhan }\end{array}$ \\
\hline
\end{tabular}

Table 2: Some of the Pottali Rasayanas (PTR)

\begin{tabular}{|c|c|c|c|c|}
\hline Sr. No & Pottali Rasayana & Constituents & Dose \& Anupana & Uses \\
\hline 1 & $\begin{array}{l}\text { Hiranyagarbha Pottali } \\
\text { Rasa }{ }^{[19]} \\
\quad \text { (Gandhaka } \quad \text { Drava } \\
\text { method) }\end{array}$ & $\begin{array}{l}\text { Suvarna Bhasma- } 10 \text { Karsha } \\
\text { Vishuddha Kajjali-1 Karsha } \\
\text { Sh. Gandhaka-1Tanka } \\
\text { (3gms) } \\
\text { Suvarnatanutantu- } 6 \text { Ratti }\end{array}$ & $\begin{array}{l}\text { 1/2 Gunja }(60 \mathrm{mg}) \\
\text { Pippali (piper } \\
\text { longum), goat's milk, } \\
\text { Honey }\end{array}$ & $\begin{array}{l}\text { Rajyakshma, } \\
\text { Raktakshobha, } \\
\text { Jirnajwara, } \\
\text { Oja Kshaya }\end{array}$ \\
\hline 2 & $\begin{array}{l}\text { Taragarbha Pottali } \\
\text { Rasa (Shwetavarna) } \\
\text { [19] } \\
\text { (Gandhaka Drava } \\
\text { method) }\end{array}$ & $\begin{array}{l}\text { Roupya Bhasma-10 Karsha } \\
\text { (100 gms) } \\
\text { Parad Bhasma- } 1 \text { Karsha (10 } \\
\text { gms) } \\
\text { Vishuddha Gandhaka }-1 \\
\text { Tanka (3gms) } \\
\text { Suvarnatanutantu-6 Ratti } \\
\text { (750mgs) }\end{array}$ & $\begin{array}{l}\text { 1/2 Ratti (60mg) } \\
\text { Tulsi (holy basil } \\
\text { leaves juice,) Honey }\end{array}$ & $\begin{array}{l}\text { Prameha } \\
\text { Shukra dosha } \\
\text { Pitta vikriti } \\
\text { Mutraj Vyadhi (Urinary } \\
\text { disorders) }\end{array}$ \\
\hline
\end{tabular}




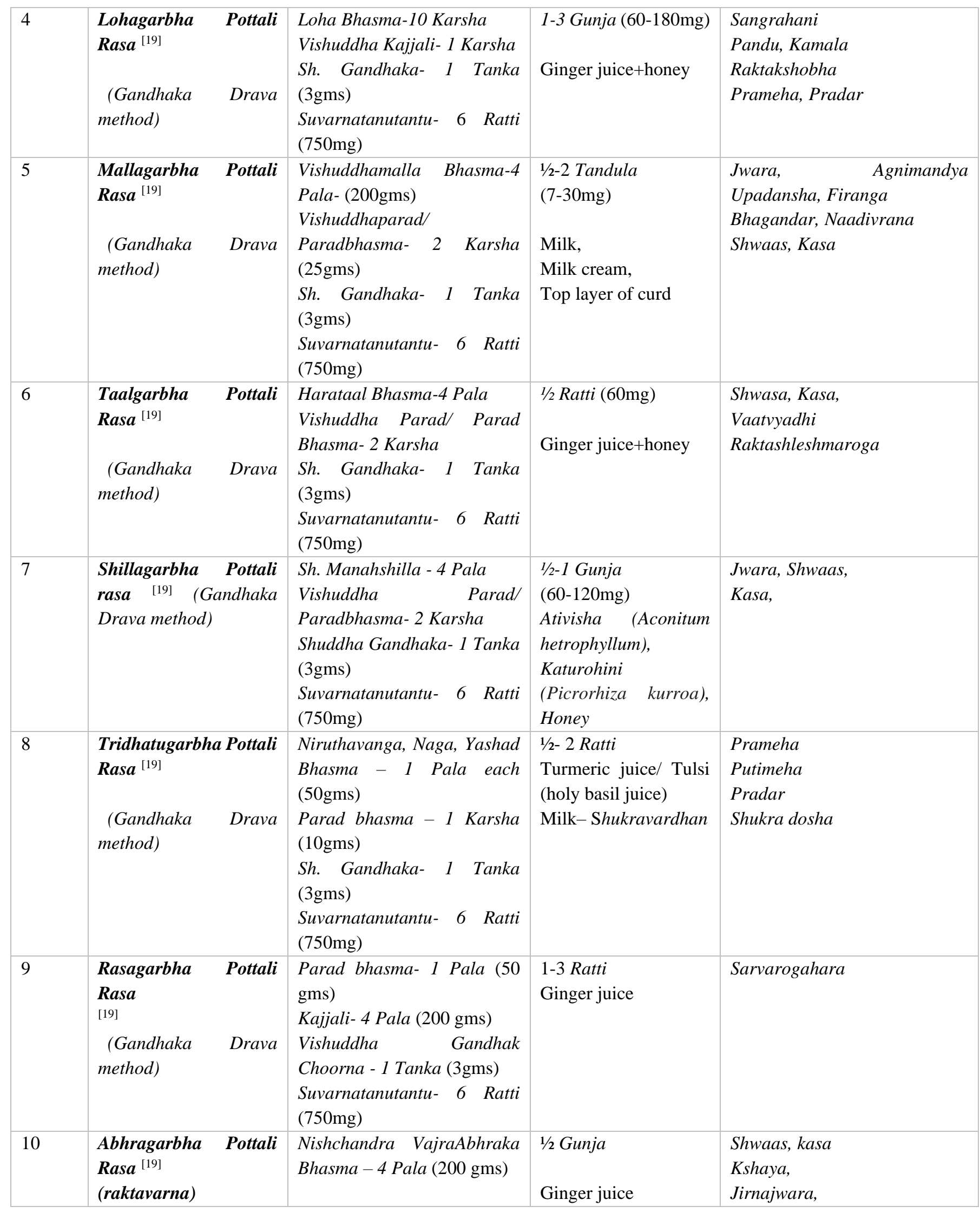




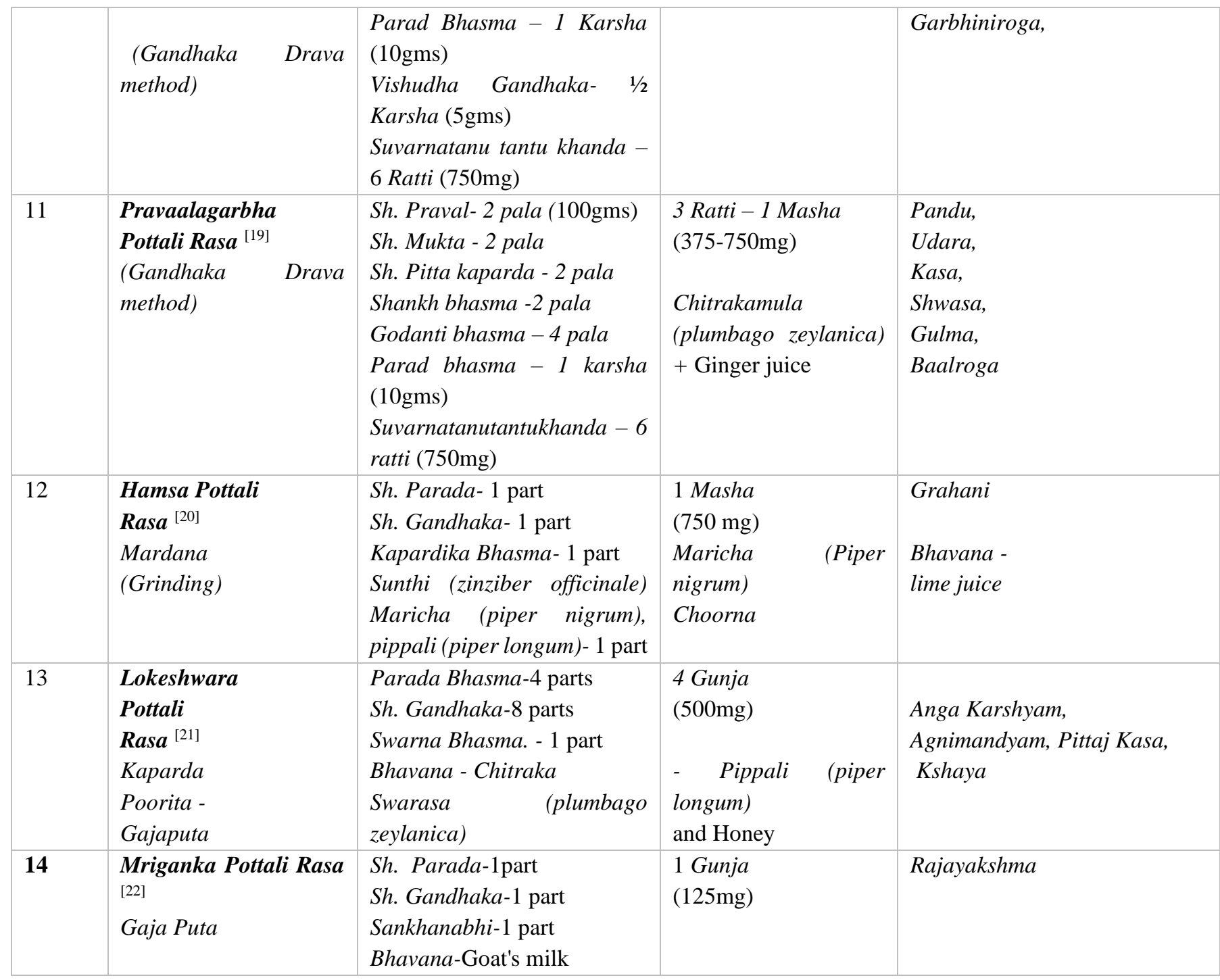

\section{DISCUSSION}

Several different References, Composition, Indications of KPR [Table no.1] \& PTR [Table no. 2] are available in classical texts of Rasashatra. There are a varied number of formulations having the same names with different compositions and indications for example Rasasindoor is explained in different classical texts in multiple ways, say as Samgunbali Jarit, Dwiguna Balijarit, and so on and can be utilized with different Anupanas (adjuvants) in different doses at different age groups. ${ }^{[23]} \mathrm{A}$ varied form of formulations has to be used at different stages of the disease, with varying Dosha-Dushya and Samprapti for different individuals.
Parada Murchanna is associated with Agni Samskara (heating) process is monitored at precisely controlled temperatures. Agni plays an important role in modifying Guru (heavy for digestion) quality of Kajjali to Laghu (light/easily digestible) quality because this change in quality is required for better absorption and assimilation to serve the therapeutic purpose. Bonds formed in Kajjali are weak, they easily breakdown in the stomach, as the further Agnisamsakara is carried out on Kajjali to form Parpati the bond becomes strong those are capable of alleviating Intestinal disorders when Agni Samasakara on Kajjali/ Parad is carried out in Sand bath gradually for longer time bond becomes even 
stronger which possess the strength to get absorbed through microchannels even sublingually if it is rotated over stone for few times during administration. This technique potentiates the constituents bonding between the constituents forming a coordinating complex with a wide spectrum and high therapeutic efficacy, with a minimum dose. In KPR \& PTR the ingredients are made into a compact form for easy administration, preservation, and transportation. Due to a lack of practical application, the present generation of Ayurvedic physicians is not aware of these medicines.

Let's see Hemgarbha Pottali, the main constituents are - Shuddha Parad, which is a potent Antiaging agent (Jara), Another main constituent is Gandhaka which is strong Vishaghna, Jantughna (antimicrobial), Krimighna (homicidal), and Deepan-Pachana. Because of its synergistic action with Parad, it also potentiates the medicinal and other properties of Parad. So, the Gandhak is written as Sutendra Viryaprada and Sutajeet in Ayurveda. The next constituent of Hemgarbha Pottali is Swarna (gold), which is a well-known Immunomodulator, Rejuvenate, Strengthens the body, acts as a nervine tonic by alleviating Tridoshas (humour) [24]. In Hemagarbh Pottali Rasa, Tamra is also used which is useful in Shwasa-kasa, Krimi roga, and Pandu roga (anaemia) ${ }^{[25]}$. It is also good medicine for Liver diseases and a well-known cardiac stimulant. So, by the combination of all i.e. purified mercury, sulphur \& gold, thus it is must understand correctly the Guna, Karma, Doshaghnata, Rogaghnata, Prabhava of the individual constituents and hence the potential of the compound.

\section{Applications of KPR \& PTR in Practice}

- Malla Sindoor ${ }^{[26]}$ It is Tikshana (sharpness) and Ushna-Virya (hotness), It stimulates Lungs, Heart, therefore it is useful in Bronchial Asthama, bronchiectasis, in conditions of Kapha Sanchaya (accumulation of phlegm). If Kapha is situated in the lungs and lungs are unable to expectorate or due to weakness in lungs in such conditions Mallasindoor is very effective. Due to its Ushna and Tikshanatva, Mallasindoor is not advisable in high-grade fever which may exacerbate the disease. In Pneumonitis on later stages where due to weakness of lung, Respiratory rate is decreased Malla Sindoor is useful medicine. Mallasindoor is contraindicated in Pitta Bhuyishthadi Vikar (disorders caused due to aggravation of humour Pitta) and children.

- Mallasindoor and Panchasuta Rasayanas are Kaphasanshodhaka (cough purifier), but Panchasuta Rasayana is not as Tikshana and Ushna as Mallasindoor. It effective in Pleural effusion/ pleuritis. ${ }^{[27]}$

- Panchasuta is also used in Asthama. It is contraindicated in Shushka Kasa Yukta Pittaj Shawas (dry cough incorporated with breathlessness) or where there is no Kahapha Strao (secretion of mucous). Here Sameerpanaga acts as a mucolytic agent and thereby giving relief to the patient. Manikya rasa cures especially - dry cough \& repeated episodes of cough. ${ }^{[28]}$

- Abhragarha Pottali rasa can be used in diseases where etiopathogenesis is due to obstruction in channels (Strororodhjanya Samprapti), Jwara (fever), Shwasa (respiratory disorders), Udar, Sangrahani (Intestinal disorders), etc.

- Pachasuta is liver stimulating, when any disease has occurred due to impairment of the liver Panchasuta is beneficial in acute conditions. [28]

- When there is a decrease in specific gravity of urine of Prameha patient complaining about frequent urination in such kind of condition Manikya Rasa is very good. Manikya Rasa stimulates and replenishes ureters, kidneys, urinary bladder, etc.

- Hiranyagarbha Pottali Rasa is very useful in Kapha Pradhan Vyadhi (disorders due to aggravation of Humor Kapha), when the condition of disease exceeds to Sannipata stage in disorders of Kshaya, Kasa, Shwasa, Hemiparesis, Sangrahani, and even heart diseases.

- Loha Bhasma in Lohagarbha Pottali Rasa is Uncutous, Tridoshaghna, Aamdoshaghna, Balya, 
thus useful in Anaemic conditions such as Sickle cell Anaemia, Spleenomegaly, Haemorrhoids, etc.

- TamragarbhaPottaliRasa, contains Tamra Bhasma which is Madhur Vipaki, Ushnavirya has scrapping properties, is useful in liver disorders, Spleenomegaly, weak digestion, and disorders associated with obstruction in channels due to vitiated Kapha Pitta.

According to modern medicine use of mercury is believed to be toxic for kidneys, but various Samskaras on Rasa Dravyas (metals, minerals, gems) during the process convert them to non-toxic, palatable, having therapeutic properties. For instance, Makardhwaja is an Ayurvedic formulation that is prepared using Mercury, Gold, etc. But when studies were conducted on it, the drug was found not to be nephrotoxic but protective to the kidneys from nephrotoxins. ${ }^{[29]}$. Modern medicines are proving insufficient for curing disease, many of them provide only symptomatic relief or acts as a placebo and also causing deleterious effects on the body on long time consumption. In this way, all KPR and PTR can be used judiciously in many non-curable, complicated, dreadful diseases. By special process of purification of mercury, the toxicity of the mercury is up to that extent minimized, where mercury becomes edible and converts its inherent property for healing of the human body ailments. ${ }^{[30]}$

\section{CONCLUSION}

KPR \& PTR are miraculous medicines that have been neglected over the centuries maybe for the cost and typical preparatory procedures involved. Due to this reason, they did not get the limelight. KPR \& PTR get absorbed quickly and act as a metabolic catalyst, thus carrying the herbs they contain directly to the cellular level. The efficacy of some Rasa preparations increases over time has no expiry date. The advantage of KPR \& PTR is the a) preservation of Rasa medicines is much easier than herbal preparations. $b$ ) The taste of KPR \& PTR is generally neutral. c) Rasaaushadhis are easy to administer.

Advanced analytical techniques can be useful for the characterization of Rasa preparations, but they fail to give information regarding its pharmacodynamics. The concept of the increased potency of KPR \& PTR with the increase in the proportion of Gandhaka added could not be proved analytically despite using the modern, sophisticated instruments though it has to be proved clinically. Appropriate selection of Anupana (adjuvants) as per classic literature enhances the efficacy of these Rasa Aushadhis according to disease, Prakruti, Bala, Vaya (age), and selection of proper drug one can fight almost every infectious disease using Rasa Aushadhis. Keeping all the above concepts in mind, judicial utilization of KPR \& PTR is the need of the hour in Ayurvedic practice. To full fill these criteria clinical research may be carried out.

\section{REFERENCES}

1. Sadanand Sharma; Rasatarangini, Murchanna Vidnyaniya, Kashinath Shastri, Motilal Banarsidas, Delhi: 1979, 11 Editions, Pp.102

2. Sadanand Sharma; Rasatarangini, Murchanna Vidnyaniya, Kashinath Shastri, Motilal Banarsidas, Delhi: 1979, 11 Editions, Pp.103

3. Sadanand Sharma; Rasatarangini, Murchanna Vidnyaniya, Kashinath Shastri, Motilal Banarsidas, Delhi: 1979, 11 Editions, Pp.125

4. Sadanand Sharma; Rasatarangini, Murchanna Vidnyaniya, Kashinath Shastri, Motilal Banarsidas, Delhi: 1979, 11 Editions, Pp.129

5. Shyamrao Dhondopant Kulkarni, Ayurvediya Rasaushadhi Nirmaan, Chapter No.14, Continental Prakashan Pune, 1981, Pp.443

6. Shyamrao Dhondopant Kulkarni, Ayurvediya Rasaushadhi Nirmaan, Chapter No.13, Continental Prakashan Pune, 1981, Pp.431

7. Bramhashankar Shashtri, Yoga Ratnakar, Purvardhagat, Parad Prakaran, Verse No. 1-8 "Vidyotini "Hindi Commentary; Choukhamba Prakashan, Varanasi, 2013; Pp.No.155

8. Sadanand Sharma; Rasatarangini, Murchanna Vidnyaniya, Kashinath Shastri, Motilal Banarsidas, Delhi: 1979, 11 Editions, Pp.140

9. Gangadhar Shastri Gopalrao Gune Ayurvediya Aushadhi Gunadharma Shastra Part 4; $7^{\text {th }}$ Edition1992, Pp. 87

10. Shyamrao Dhondopant Kulkarni, Ayurvediya Rasaushadhi Nirmaan, Continental Prakashan Pune, 1981, Chapter No.14, Pp.472 
11. Sadanand Sharma; Rasatarangini, Murchanna Vidnyaniya, Kashinath Shastri, Motilal Banarsidas, Delhi: 1979, 11 Editions, Pp.115-117

12. Sadanand Sharma; Rasatarangini, Murchanna Vidnyaniya, Kashinath Shastri, Motilal Banarsidas, Delhi: 1979, 11 Editions, Pp.108-111

13. Ras Chandashu; Updansha Chiktsaadhyaya; Kendriya Ayurveda Evam Sidhaanusandhan Parishad, New Delhi,2011 Pp345

14. Hari Prapannaji, Rasayogsagar Vol. 2, Krushnadas Academy, Varanasi; 1983, $2^{\text {nd }}$ Edition; Pp. 157

15. Gangadhar Gopalrao Gune Ayurvediya Aushadhi Gunadharma Shastra Part 4; Chaukhamba Sanskrit Pratishthan, 1992, $7^{\text {th }}$ Edition, Pp.91

16. Hari Prapannaji, Rasayogsagar Vol. 2, Krushnadas Academy, Varanasi; 1983, $2^{\text {nd }}$ Edition; Pp.166

17. Gangadhar Gopalrao Gune Ayurvediya Aushadhi Gunadharma Shastra Part 4; Chaukhamba Sanskrit Pratishthan, 1992, $7^{\text {th }}$ Edition, Pp.77

18. Govindas Sen, Bhaishajya Ratnavali, Pramehapidika Adhikar, Verse No 161-167, Siddhiprada Commentary by Siddhinandan Mishra, Choukhamba Surbharti Prakashan, Varanasi, 2013; $1^{\text {st }}$ Edition, Pp.No. 721

19. Hariprapannaji Sharma, Rasayoga Sagar, Vol. I, Pottali Rahasyam 1983, 2nd Edition, Krishnadas Academy, Varanasi, Pp-580 -582

20. Govindas Sen, Bhaishajya Ratnavali, Grahanirogadhikar, Verse No 234-235, Siddhiprada Commentary by Siddhinandan Mishra, Choukhamba Surbharti Prakashan, Varanasi, 2013; $1^{\text {st }}$ Edition, Pp.No. 274

21. Govindas Sen, Bhaishajya Ratnavali, Rajyakshama Adhikar, Verse No 189-195, Siddhiprada Commentary by Siddhinandan Mishra, Choukhamba Surbharti Prakashan, Varanasi, 2013; $1^{\text {st }}$ Edition, Pp.No.423

22. Vaagbhat, Rasratna Sammuchya, Choukhamba Amarbharti Prakashan; 2015; Chapter 14, Verse 20-22, Pp. 271

23. Sadanand Sharma; Rasatarangini, Murchanna Vidnyaniya, Kashinath Shastri, Motilal Banarsidas, Delhi: 1979, 11 Editions, Pp.143-148

24. Vagbhatacharya, Rasa Ratna Samucchaya, Edited by Sdharmanandana Sharma, Motilal Banarsi Das, Varanasi, 2nd Edition - 1996

25. Govindas Sen, Bhaishajya Ratnavali, Rajyakshama Adhikar,Verse No 186-188, Siddhiprada Commentary By Siddhinandan Mishra, Choukhamba Surbharti Prakashan, Varanasi, 2013; $1^{\text {st }}$ Edition, Pp.No.423
26. Gangadhar Gopalrao Gune Ayurvediya Aushadhi Gunadharma Shastra Part 4; Chaukhamba Sanskrit Pratishthan, 1992, $7^{\text {th }}$ Edition, Pp.74

27. Gangadhar Gopalrao Gune Ayurvediya Aushadhi Gunadharma Shastra Part 4; Chaukhamba Sanskrit Pratishthan, 1992, $7^{\text {th }}$ Edition, Pp.77

28. Gangadhar Gopalrao Gune Ayurvediya Aushadhi Gunadharma Shastra Part 4; Chaukhamba Sanskrit Pratishthan, 1992, $7^{\text {th }}$ Edition, Pp. 81

29. Jambla Neha, Saroch Vikas, Johar Smita. Dose Schedule of Rasa Aushadhis. J Ayurveda Integr Med Sci 2016; 2:98-101

30. Sadanand Sharma; Rasatarangini, Paradasya Ashtasamskara Vidnyaniya, Kashinath Shastri, Motilal Banarsidas, Delhi: 1979, 11 Edition, Pp.73

\section{Source of Support: Nil Conflict of Interest: None Declared}

How to cite this URL: Kannan Mani et al: Judicial Utilization Of Kupipakwa And Pottali Rasayanas Boon For Ayurvedic Practice. International Ayurvedic Medical Journal \{online\} 2021 \{cited July, 2021\} Available from: http://www.iamj.in/posts/images/upload/3003_3011.pdf 